\title{
MENGENAL UKURAN DENGAN PENDEKATAN PMRI PADA ASPEK KOGNITIF PENDIDIKAN ANAK USIA DINI
}

\author{
Rosmalia Septiana, Ratu Ilma Indra Putri, Yusuf Hartono \\ Jurusan Magister Pendidikan Matematika, Universitas Sriwijaya \\ e-mail: rosmaliaseptiana@gmail.com,ratu.ilma@yahoo.com
}

\begin{abstract}
Abstrak
Penelitian ini bertujuan untuk menghasilkan lintasan belajar anak usia dini yang dapat membantu siswa mengembangkan aspek kognitif khususnya kemampuan mengenal ukuran. Metode yang digunakan adalah Design Research yang terdiri dari tiga tahap, yaitu : desain pendahuluan (preliminary design), desain percobaan mengajar (pilot experiment dan teaching experiment), dan analisis retrospektif. Dalam penelitian ini, serangkaian aktivitas pembelajaran didesain dan dikembangkan berdasarkan pendekatan PMRI. Penelitian ini melibatkan anak usia dini dengan rentang usia $4-5$ tahun di TK Binama Global School. Penelitian ini menghasilkan Learning Trajectory yang memuat serangkaian proses pembelajaran anak usia dini dalam mengembangkan aspek kognitif dengan perkembangan dasar mengenal ukuran. Melalui aktivitas ini, siswa dibimbing untuk dapat mengenal ukuran melalui permainan yang disukai siswa, yaitu menuangkan air. Hasil dari penelitian menunjukkan bahwa pembelajaran dengan pendekatan PMRI dapat membantu siswa mengembangkan aspek kognitif dengan perkembangan dasar mengenal ukuran dan menambah pengalaman belajar yang dapat diterapkan di sekitar lingkungan siswa sehari-hari.
\end{abstract}

Kata kunci : disain penelitian, pmri, paud, kognitif

\section{RECOGNIZING THE SIZE WITH PMRI APPROACH TO COGNITIVE ASPECTS OF EARLY CHILDHOOD EDUCATION}

\begin{abstract}
This research aims to generate trajectories of early childhood learning that can help students to develop particular cognitive ability in recognizing the size. The method used is Design Research which consists of three stages: preliminary design, pilot experiment and teaching experiment, and retrospective analysis. In this research, a series of learning activities are designed and developed based on the PMRI approach. This research involves early childhood with age range 4 - 5 years at TK Binama Global School. This research resulted Learning Trajectory which contains a series of early childhood learning process in developing cognitive aspects with basic development of recognize the size. Through this activities, students are guided to be able to recognize the size using their favourite games like pouring the water. The results of this research show that learning by PMRI approach can help students develop useful cognitive aspects specially in recognize the size and add student's learning experience that can be applied in the daily life of the students.
\end{abstract}

Keywords: design research, pmri, early childhood, cognitive

PENDAHULUAN

Menurut

Undang-Undang

Republik Indonesia Nomor 20 Tahun 2003 tentang Sistem Pendidikan Nasional pasal 28 menyatakan bahwa (1) Pendidikan anak usia dini diselenggarakan sebelum jenjang
8 dasar, (2) Pendidikan anak usia dini dapat diselenggarakan melalui jalur pendidikan formal, nonformal, dan/atau informal, (3) Pendidikan anak usia dini pada jalur pendidikan formal berbentuk Taman Kanak-kanak (TK), Raudatul 
Athfal (RA), atau bentuk lain yang sederajat, (4) Pendidikan anak usia dini pada jalur pendidikan nonformal berbentuk Kelompok Bermain (KB), Taman Penitipan Anak (TPA), atau bentuk lain yang sederajat, (5) Pendidikan anak usia dini pada jalur pendidikan informal berbentuk pendidikan keluarga atau pendidikan yang diselenggarakan oleh lingkungan.

Anak usia dini memiliki karakteristik yang unik dan tersendiri sesuai dengan tahap usianya. Usia dini (06 tahun) merupakan masa keemasan sehingga stimulasi seluruh aspek perkembangan dapat berperan penting untuk perkembangan anak. Untuk berkembang secara optimal pada awal kehidupan anak perlu diberikan pendidikan yang harus dilakukan dengan kegiatan yang sesuai dengan kondisi anak dan dekat dengan kehidupan sehari - hari anak.

Secara garis besar, Piaget (dalam Suparno, 2001), mengelompokkan tahapan perkembangan menjadi empat tahap kematangan kognitif pada anak, yang berurutan dan saling berkaitan, perkembangan pada tahap sebelumnya akan berpengaruh pada tahap selanjutnya, yaitu :

a. Tahap sensorimotor (0-2 tahun), pada tahap ini anak-anak mulai menunjukkan pemikiran berdasarkan tindakan inderawi

b. Tahap praoperasi (2-7 tahun), anakanak mulai menggunakan simbol untuk menunjukkan suatu benda dan mengungkapkan pemikirannya dengan menggunakan bahasa

c. Tahap operasi konkret (7-11 tahun), anak-anak mulai menggunakan aturan yang jelas dan logis

d. Tahap operasi formal (11 tahun dewasa), munculnya pemikiran yang abstrak, hipotesis, deduktif, dan induktif.

Anak usia dini berada pada tahap operasi praoperasi, pada tahap ini anak usia dini diharapkan untuk dapat berkembang dengan baik di segala aspek perkembangan yaitu perkembangan moral dan nilai - nilai agama, sosial dan emosional, bahasa, kognitif, seni dan fisik motorik. Untuk mendukung perkembangan anak secara optimal diperlukan stimulan yang tepat.

Aspek kognitif pada anak diharapkan dapat berkembang secara optimal. Di dalam aspek kognitif ada beberapa kemampuan yang perlu dikembangkan anak, salah satunya kemampuan untuk mengenal ukuran dimana siswa dapat membedakan banyak sedikit, tinggi - rendah, dan besar - kecil. Mengenal ukuran merupakan salah satu indikator aspek kognitif pada anak usia dini dan termasuk dalam subjek matematika pada pembelajaran formal anak usia dini di Taman Kanak - Kanak (TK).

Pembelajaran matematika pada anak usia dini masih belum menunjukkan perkembangan yang signifikan, menurut Nunes \& Bryan (Papadakis 2016) terdapat fenomena anak yang memiliki kemampuan matematika yang bagus di kelas tetapi buruk di kehidupan sehari- hari. Matematika akan menarik minat anak usia dini jika anak usia dini menyadari pentingnya matematika sebagai penyelesaian masalah dalam kehidupan sehari-hari.

Freudental (Soedjadi, 2007) menyatakan bahwa "Mathematics is human activity" oleh karena itu matematika dapat dikaitkan dengan aktivitas manusia sehari-hari.

Dua pandangan yang penting dari Freudenthal tentang PMRI adalah (1) mathematic must be connected to reality; and (2) mathematics as human activity (Zulkardi \& Putri, 2006). Pertama, matematika seharusnya dengan siswa dan berkaitan dengan kehidupan sehari-hari. Kedua, ditekankan bahwa matematika sebagai aktivitas manusia sehingga siswa diberikan kesempatan untuk melakukan aktivitas pembelajaran di setiap topik matematika. 
Menurut Freudenthal dalam Gravemeijer (2004) dalam pembelajaran RME terdapat tiga prinsip yang dapat dijadikan sebagai acuan penelitian, yaitu : (1) Guided reinvention and progressive mathematizing, phenomenology, Didactical (3) Self-developed pedels. Ada lima karakteristik pembelajaran matematika realistik, yaitu : (1) Penggunaan konteks, (2) Penggunaan model matematisasi progresif,

Pemanfaatan hasil konstruksi siswa, (4) Interaktivitas, (5) Keterkaitan.

Dalam menerapkan pendekatan PMRI dalam pembelajaran di kelas juga terdapat beberapa norma sosial yang sebaiknya juga diterapkan di kelas. Menurut Putri (2015), ada tiga aspek penting dalam proses pembelajaran, menurut pandangan sosio-konstruktivis, yaitu : (1) Norma sosial yang terdiri dari peraturan yang disetujui oleh guru dan siswa selama belajar di kelas (2) Norma sosial matematika, yaitu norma yang berbicara tentang perbedaan matematika, kecanggihan matematika, dan penerimaan pemecahan masalah matematika, (3) Praktik kelas matematika yang melibatkan dokumentasi perkembangan matematika siswa, klasik atau individual.

Proses manusia menemukan dan membangun matematika dalam aktivitas sehari-hari secara tidak langsung telah mengasah kemampuan matematika, sehingga di dalam pembelajaran matematika akan lebih berkesan jika siswa yang membangunnya sendiri daripada diberikan oleh guru.

Berdasarkan penelitian Papadakis (2016) menyatakan bahwa teknik mengajar yang menggunakan pendekatan PMRI memberikan hasil yang signifikan terhadap perkembangan kompetensi matematika pada anak usia dini.

Menurut Wijaya (2012), penerapan PMRI dalam kurikulum Indonesia memliki potensi tidak hanya untuk pengembangan kemampuan matematika, melainkan juga pengembangan kompetensi siswa yang lebih umum, yaitu kreativitas dan kemampuan komunikasi.

a. Pengembangan kreativitas melalui penggunaan konteks dan kegiatan eksploratif

Penggunaan konteks pada pembelajaran dapat membantu siswa mengembangkan kreativitasnya, karena siswa dipengaruhi oleh dua komponen utama, yaitu pemahaman atau intreprestasi siswa terhadap konteks serta pengetahuan awal yang dimiliki siswa. Perbedaaan ini akan mendorong siswa untuk mengembangkan strategi yang berbeda.

b. Kemampuan komunikasi

Untuk mendapatkan informasi terhadap pemahaman siswa dibutuhkan konfirmasi. Inti dari proses konfirmasi adalah komunikasi (Wijaya, 2012). Komunikasi dan interaksi sosial yang baik dapat menjadi bekal siswa dalam menjalani peran dari suatu sistem sosial masyarakat.

Menurut Mayke (Sudono, 2004), kesempatan kepada anak untuk memanipulasi, mengulang-ulang, menemukan sendiri, bereksplorasi, mempraktikkan, dan mendapatkan bermacam-macam konsep serta pengertian yang tidak terhitung banyaknya dapat dibangun dengan cara bermain pada saat pembelajaran. Disinilah proses pembelajaran terjadi. Anak-anak mengambil keputusan sendiri, memilih, menentukan, mencipta, memasang, membongkar, mengembalikan, mencoba, mengeluarkan pendapat, memecahkan masalah, mengerjakan secara tuntas, bekerja sama dengan teman, dan mengalami berbagai perasaan.

Sudono (2006: 20) mengemukakan beberapa alasan permainan dapat dijadikan sebagai media pembelajaran. Beberapa alasan tersebut adalah sebagai berikut :

(1)Pengalaman yang kaya, bermakna, dan menarik dibutuhkan anak-anak untuk mendukung perkembangan yang optimal,

(2)Hal-hal baru yang menantang dan menarik membuat anak senang, 
(3)Kemungkinan siswa belajar makin tinggi jika kegiatan anak melibatkan visual, audio, dan audio visual, dan dapat merangsang otak sensori multimedia penting dalam pembelajaran.

(4)Pada umumnya anak senang bergerak, dengan bermain biasanya anak bergerak lebih banyak, sehingga dapat membantu dalam pembelajaran,

(5)Kegiatan yang membuat siswa dapat mengulang pembelajaran tanpa rasa bosan dan jenuh merupakan kunci pembelajaran yang baik.

(6)Anak-anak menyukai permainan (games).

Dengan bermain sambil belajar di dalam kelas, diharapkan dapat membantu siswa dalam belajar melalui aktivitas siswa sehari-hari. Salah satu aktivitas yang dapat dijadikan permainan dalam pembelajaran kali ini adalah menuangkan air dari gelas ukur ke dalam botol.

Permainan ini dapat membantu siswa untuk mengembangkan aspek motorik siswa, dan juga dengan bimbingan dan stimulasi dari guru dapat membimbing siswa untuk juga mengembangkan aspek kognitif siswa.

\section{METODE}

Artikel ini merupakan bagian dari tesis yang berjudul "Desain Pembelajaran Aspek Perkembangan Kognitif dengan Menggunakan Permainan pada Anak Usia Dini".

Penelitian ini menggunakan metode penelitian design research yang mendesain pembelajaran aspek perkembangan kognitif dengan pendekatan PMRI pada anak usia 4-5 tahun di TK Binama Global School yang berjumlah 10 orang.

Design research mempunyai lima karakteristik, yaitu sebagai berikut (Akker dkk., 2006:5) :

a) Interventionist: merancang tujuan penelitian merupakan campur tangan di dunia riil. b) Iterative: penelitian memasukkan suatu desain siklus pendekatan, evaluasi, dan revisi.

c) Process oriented: berfokus dalam memahami dan memperbaiki intervensi.

d) Utility oriented: kebaikan suatu desain adalah diukur, dalam bagian, oleh kepraktisannya untuk pengguna dalam konteks riil.

e) Theory oriented: desain didasarkan pada masalah secara teoritis, dan pengujian lapangan dari desain menambah untuk membangun teori.

Pada design research terdapat dua aspek penting, dimana keduanya diarahkan pada aktivitas dalam kegiatan pembelajaran peserta didik. Dua aspek tersebut sebagai berikut :

a. Hypothetical Learning Trajectory Hypothetical Learning Trajector (HLT) merupakan instrumen yang digunakan untuk memandu proses penelitian. Menurut Simon dalam Bakker (2004), HLT terdiri dari komponen: (1) tujuan pembelajaran yang mendefinisikan arah (tujuan Pembelajaran), (2) kegiatan belajar, dan (3) hipotesis proses belajar untuk memprediksi bagaimana pikiran dan pemahaman siswa akan berkembang dalam konteks kegiatan belajar.

HLT digunakan sebagai bagian dari apa yang disebut siklus mengajar matematika (mathematical learning cycle) untuk satu atau dua pembelajaran, atau bahkan untuk lebih dari dua pembelajaran. HLT dapat menghubungkan antara teori pembelajaran (intructional theory) dan percobaan pembelajaran secara konkrit. HLT digunakan untuk membimbing proses percobaan pembelajaran yang sudah ditentukan dalam bentuk HLT.

b. Local Intructional Theory

Local Intructional Theory (LIT) merupakan teori tentang proses dimana peserta didik mempelajari suatu topic matematika dan teori tentang media atau perangkat yang digunakan dalam membantu proses pembelajaran topik tersebut (Gravemeijer dan van Eerde, 
2009). Pada LIT, pendidik merancang sebuah HLT untuk topik matematika dengan memilih aktivitas sesuai dengan dugaan-dugaan yang muncul pada proses pembelajaran (Wijaya, 2008b). Sehingga LIT merupakan kerangka berpikir untuk mendesain dan mendeskripsikan HLT.

Desain pembelajaran yang dilakukan dengan mendesain dan melalui tiga tahap (Putri, 2012), yaitu:

\section{1) Preliminary}

Pilot Experiment atau percobaan mengajar pendahuluan untuk mengujicobakan HLT yang telah dirancang pada siswa dalam kelompok kecil guna mengumpulkan data dalam menyesuaikan dan merevisi HLT awal untuk digunakan pada tahap teaching experiment nantinya. Dalam penelitian percobaan ini, peneliti melakukan diskusi dengan guru model agar HLT yang telah didesain dapat mencapai sasaran sesuai dengan tujuan pembelajaran. Diskusi ini sangat diperlukan agar adanya komunikasi yang baik antara peneliti dan guru model sehingga saran-saran dari guru model dapat didengar dan digunakan untuk membantu peneliti dalam menyesuaikan pendesainan HLT awal karena guru lebih tahu kondisi siswa yang akan menjadi sampel penelitian.

\section{2) Teaching Experiment}

Tahap teaching experiment atau percobaan mengajar merupakan tahap inti dari design research karena pada tahap ini, HLT yang telah didesain atau dirancang dan diperbaiki sebelumnya akan diujicobakan di kelas sebenarnya yang menjadi subyek penelitian. Hasil dari tahap ini akan digunakan untuk menjawab masalah dalam penelitian ini. Guru model bertindak sebagai pengajar dan peneliti melakukan observasi terhadap aktivitas pembelajaran yang merupakan kemampuan komunikasi matematika siswa.

Selama proses berjalan, konjektur atau dugaan-dugaan/ide-ide dapat dimodifikasi sebagai revisi local instructional theory untuk aktivitas berikutnya. Sederetan aktivitas pembelajaran dilakukan di kelas, lalu peneliti mengobservasi dan menganalisa hal-hal yang terjadi selama proses pembelajaran berlangsung. Proses ini bertujuan untuk mengevaluasi konjekturkonjektur yang terdapat pada aktivitas pembelajaran untuk kemampuan komunikasi matematika siswa. Selama proses uji coba, setiap kegiatan direkam dengan menggunakan dokumentasi foto dan video. Beberapa siswa dipilih untuk diwawancarai selama proses berlangsung dan setelah proses berlangsung. Selain itu, hasil kerja siswa dikumpulkan untuk dianalisis.

3) Restropective Analysis

Data yang diperoleh dari tahap teaching experiment dianalisa dan hasil analisa ini digunakan untuk merencanakan kegiatan dan mengembangkan rancangan kegiatan pada pembelajaran berikutnya. Tujuan dari retrospective analysis secara umum adalah untuk mengembangkan local instructional theory. Pada tahap ini, HLT dibandingkan dengan pembelajaran siswa yang sebenarnya, hasilnya digunakan untuk menjawab rumusan masalah.

Pengumpulan data pada penelitian ini dilakukan dengan cara :

a. Rekaman video

Rekaman video digunakan dalam penelitian ini untuk merekam aktivitas peserta didik. Selain itu, juga merekam interaksi pendidik dengan peserta didik sehingga strategi pemecahan masalah dan aktivitas peserta didik dapat diukur dan diobservasi. Rekaman video dilaksanakan pada tahap pilot experiment dan teaching experiment yang ditujukan untuk merekam seluruh kegiatan yang terjadi didalam kelas.

b. Observasi

Proses pengamatan langsung selama proses pembelajaran yang telah didesain sebelumnya oleh peneliti dengan menggunakan lembar observasi. Observasi dilakukan pada tahap pilot experiment dan teaching experiment.

c. Dokumentasi

Mendokumentasikan seluruh hasil 
kegiatan siswa berupa foto dan rekaman video selama kegiatan pembelajaran dan hasil jawaban siswa sebagai bukti pelaksanaan penelitian. Penggunaan dokumentasi berupa kamera foto dan rekaman video dilakukan pada tahap pilot experiment dan teaching experiment.

d. Pre-test dan Post-test

Pre-test dilaksanakan bertujuan untuk mengetahui tingkat pemahaman awal siswa yang dijadikan subjek penelitian dan apa yang seharusnya mereka pelajari. Data ini berupa jawaban, strategi dan alasan yang digunakan peserta didik untuk menyelesaikan masalah yang diberikan. Data dapat diperoleh dari lembar Pre-test dan wawancara terhadap siswa. Pre-test dilaksanakan sebelum pembelajaran pada waktu penelitian teaching experiment. Post-test dilaksanakan setelah proses yang bertujuan untuk mengetahui tingkat pemahaman siswa terhadap materi yang diajarkan dengan desain yang dirancang dan apa saja yang telah dipelajari.

\section{HASIL DAN PEMBAHASAN Hasil}

Penelitian ini dimulai dari tahap preliminary design, dimana peneliti mengkaji literatur, menemui guru model, dan berdiskusi tentang siswa yang akan menjadi subjek penelitian dan kurikulum pembelajaran yang akan didesain.

Berdasarkan diskusi peneliti dan guru model, peneliti memutuskan untuk mendesain aktivitas pembelajaran pada aspek kognitif dengan perkembangan dasar siswa dapat mengenal ukuran.

Dari guru model juga, peneliti mengetahui bahwa siswa yang akan menjadi subjek penelitian menyukai permainan yang melibatkan aktivitas menuangkan air dari satu wadah ke wadah lainnya.

Setelah itu, peneliti mendesain Hypothetical Learning Trajectory (HLT) sebagai gambar alur pembelajaran aspek perkembangan kognitif dengan perkembangan dasar mengenal ukuran menggunakan pendekatan PMRI.

Tahap selanjutnya setelah diperoleh HLT adalah dengan mengujicobakan HLT tersebut pada tahap pilot experiment yang dilakukan oleh peneliti sendiri sebagai guru dengan 6 anak berusia 4 tahun bukan subjek penelitian.

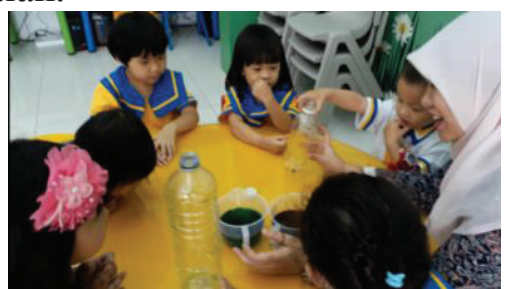

Gambar 1. Pilot Experiment

Setelah dilakukan perbaikan terhadap HLT pada pilot experiment, kemudian diadakan teaching experiment.

Pembelajaran pada tahap teaching experiment dimulai dengan pembukaan agar siswa menjadi lebih bersemangat dan siap dalam belajar yaitu tanya jawab singkat tentang kegiatan sehari - hari.

Sebelum melakukan aktivitas pembelajaran, guru model memberikan pre-test kepada siswa. Pre-test terdiri dari 2 buah worksheet.

Siswa diminta untuk membandingkan diantara dua gambar yang berisi air, mana yang berisi lebih banyak dan mana yang berisi lebih sedikit, sesuai instruksi yang telah diberikan di worksheet, siswa diminta untuk menulis kata more pada gambar yang berisi lebih banyak air dan less pada gambar yang berisi lebih sedikit air di dalam kotak yang disediakan di bawah masing masing gambar.

Pada pre-test pertama, 8 siswa dapat menjawab dengan benar dan hanya 2 siswa yang masih belum bisa menjawab dengan benar.

Pada pre-test kedua, siswa diberikan lima buah kertas yang bergambar gelas dengan isi yang berbeda. Siswa diminta untuk meyusun 5 buah gelas dari gelas kosong ke gelas penuh dan menempelnya secara berurutan sesuai dengan angka yang disediakan pada lembar 
worksheet. Angka 1 untuk gelas yang kosong sampai angka 5 untuk gelas yang paling penuh.

Hanya ada 4 siswa yang dapat menyusun gelas dengan benar dan 6 siswa masih belum bisa menyusun gelas dengan benar. Setelah tahap pre-test, guru dan siswa akan memulai aktivitas pembelajaran.

Pada saat aktivitas pembelajaran, guru mengenalkan alat dan bahan yang akan digunakan pada aktivitas kali ini. Siswa terlihat antusias dan siap untuk belajar. Hal ini dapat dilihat dari siswa yang menunjukkan sikap antusias dan rasa penasaran pada saat guru mengeluarkan dan mengenalkan alat dan bahan yang akan digunakan pada aktivitas pembelajaran hari ini.

Siswa juga menunjukkan sikap yang baik di kelas dengan duduk rapi dan mengikuti peraturan kelas yang telah disepakati seperti mengankat tangan jika ingin bertanya dan menyampaikan pendapat, dan memperhatikan penjelasan guru dengan antusias.

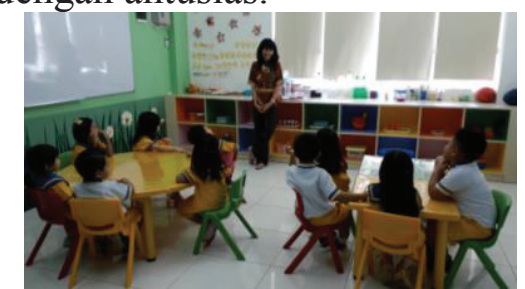

Gambar 2. Teaching Experiment

Selanjutnya, guru mulai menuangkan air ke dalam botol sambil melakukan diskusi tanya jawab dengan siswa. Pada saat air di dalam botol siswa diminta untuk memilih dari salah satu botol yang terlihat berisi lebih banyak air. Siswa serempak memilih botol kecil yang berisi lebih banyak air.

Guru kemudian meminta seluruh siswa untuk maju dalam grup yang terdiri dari 2 orang dan menuangkan kembali air dari botol ke dalam gelas ukur untuk melihat apakah air terlihat lebih banyak atau lebih sedikit jika dituang ke dalam wadah yang sama. Kemudian siswa menuangkan kembali ke dalam botol.

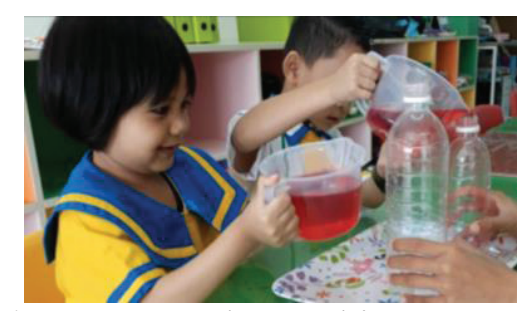

Gambar 3. Naya dan Fathir menuang air Berikut kutipan percakapan siswa dan guru pada saat siswa diminta untuk menuangkan air dan mengamati perbedaan isi air

Guru : Nah botolnya udah terisi ya, ini botol yang besar, ini botol yang kecil. Sekarang botol yang mana yang banyak isinya ?

Naya : Ini (botol besar).

Fathir : Ini (botol kecil).

Guru : Wah beda ya jawabannya, Naya kenapa pilih yang ini (besar)?

Naya : Tapi gak ada isi.

Fathir : Tadi Naya cuma sedikit, nambahnya cuma segini.

Guru : Ooh, kalau Fathir kenapa pilih yang ini (kecil)?

Fathir : Kalau punya Fathir banyak botolnya jadi penuh. Kalau yg ini (kecil) cepat penuhnya. Kalau yang ini (besar) lama penuhnya

Guru : Kenapa lama?

Fathir : Kalau airnya mau naik, lama naiknya.

Selanjutnya juga ada grup yang terdiri dari Dimaz dan Felicia yang mencoba untuk menuangkan air secara langsung.

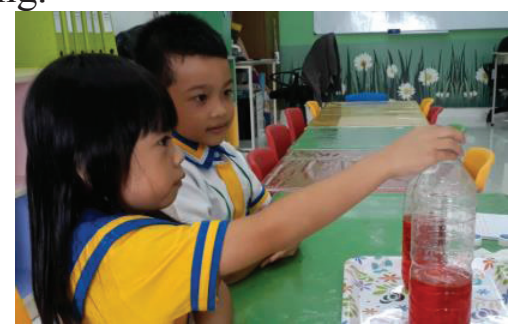

Gambar 4. Felicia dan Dimaz membandingkan air

Berikut kutipan percakapan Dimaz, Felicia, dan guru model pada saat aktivita pembelajaran

Guru : Tingginya sama gak airnya? 


\begin{tabular}{|c|c|}
\hline Dimaz & Sama \\
\hline Guru & $\begin{array}{l}\text { Nah sekarang kalau botolnya } \\
\text { sama gak? }\end{array}$ \\
\hline Felicia & Beda \\
\hline Guru & $\begin{array}{l}\text { : Ada yang botolnya ?.... ada } \\
\text { yang botolnya ?... }\end{array}$ \\
\hline Dimaz & Big, small \\
\hline Guru & $\begin{array}{l}\text { Nah sekarang Dimaz dan } \\
\text { Felic, tuang air di jug ke } \\
\text { dalam botol. Menurut Dimaz } \\
\text { dan Felicia, mana isi yang } \\
\text { lebih banyak? }\end{array}$ \\
\hline Dimaz & Yang botol kecil \\
\hline Felicia & Yang botol besar \\
\hline Guru & $\begin{array}{l}\text { Kenapa Felicia pilih botol } \\
\text { yang ini ? }\end{array}$ \\
\hline Felicia & $\begin{array}{l}\text { Karena dia botolnya gak } \\
\text { penuh jadi isinya banyak }\end{array}$ \\
\hline Guru & $\begin{array}{l}\text { : Kalau Dimaz kenapa pilih } \\
\text { botol yang kecil? }\end{array}$ \\
\hline Dimaz & $\begin{array}{l}\text { Karena ini penuh, ini karena } \\
\text { tuangnya lebar (botol besar) } \\
\text { panjang, jadinya itu sedikit. } \\
\text { Kalau yang ini botolnya } \\
\text { kecil jadinya banyak }\end{array}$ \\
\hline
\end{tabular}

Pada saat ini, guru membimbing siswa untuk melihat botol lebih teliti, guru menunjukkan bahwa botol yang besar memiliki alas yang lebih luas dibandingkan dengan botol yang kecil sehingga permukaan air lebih tinggi dan terlihat lebih banyak dibandingkan dengan botol yang besar.

Setelah menjelaskan, guru meminta siswa untuk menjelaskan kembali kesimpulannya berdasarkan pemahaman mereka sehingga guru dapat menilai apakah siswa telah dapat mengenali ukuran.

Setelah aktivitas pembelajaran, guru memberikan post-test kepada siswa. Hasil tes akhir dapat memberikan informasi bahwa siswa memperoleh pengetahuan dan kemampuan dalam mengenal ukuran, dengan adanya aktivitas pembelajaran cukup membantu siswa dalam mengenal ukuran

Tes akhir ini terdapat satu aktivitas, yaitu siswa diminta untuk menyusun gelas dengan ukuran sama yang telah diisi air dengan isi yang berbeda. Siswa diminta untuk mengurutkan gelas dari isi yang paling sedikit ke isi yang paling banyak. Dari sepuluh siswa, 8 siswa dapat menyusun dengan benar, sedangkan 2 siswa lainnya masih bingung ketika menyusun gelas.

Meskipun hasil tes menunjukkan tidak semua siswa dapat menyusun gelas dengan benar. Namun, disini terlihat adanya perkembangan siswa dalam mengenal ukuran. Hal ini nampak dari siswa yang bisa membedakan isi air di dalam gelas tanpa bantuan dari guru.

\section{Pembahasan}

. Pelaksanaan aktivitas pembelajaran ini didesain untuk membantu mengembangkan aspek kognitif siswa. Dalam pembelajaran ini, peneliti menggunakan benda real yang dapat dilihat dan disentuh langsung oleh siswa.

Menurut Wijaya (2012: 21), konteks tidak harus berupa masalah dunia nyata namun bisa dalam bentuk permainan, penggunaan alat peraga atau situasi lain selama hal tersebut bermakna dan bisa dibayangkan dalam pikiran siswa. Dengan menggunakan konteks, selain siswa dapat dilibatkan secara aktif untuk melakukan eksplorasi permasalahan (de Lange, 1987) tetapi juga dapat menumbuhkan motivasi dan ketertarikan siswa dalam belajar.

Berdasarkan desain lintasan belajar yang telah dirancang dan dilakukan oleh peneliti, lintasan belajar untuk mengembangkan aspek kognitif siswa terdapat aktivitas dimana siswa dapat mencoba langsung kegiatan ini dengan pendekatan PMRI.

Sebelum memulai aktivitas pembelajaran, siswa diberikan tes awal (pre-test), tes awal ini berguna untuk melihat pemahaman dasar siswa, sampai dimana pengetahuan siswa tentang mengenal ukuran. Berdasarkan hasil analisis retrospektif, pada saat tes awal (pre-test) masih ada siswa yang belum mampu menjawab soal yang diberikan dengan benar. 
Pada pre-test pertama, sebagian besar siswa telah dapat membandingkan isi yang ada pada gambar gelas dan botol, dan dapat menulis kata more atau less pada kotak yang benar, hanya ada yang belum bisa menjawab karena masih belum bisa menulis dengan baik, sehingga masih dibantu oleh guru untuk menjawab secara lisan.

Pada pre-test kedua, hanya sebagian kecil siswa yang dapat menyusun lima buah gambar gelas dengan benar, sebagian besar dapat menyusun gelas pertama yang kosong dan gelas terakhir yang penuh dengan benar, tetapi tiga gelas lainnya masih disusun secara acak.

Worksheet pada pre-test kedua didesain agar siswa dapat menempelkan gambar gelas secara berurutan dari atas ke bawah berdasarkan nomor yang telah diberikan. Nomor 1 untuk gelas yang kosong dan nomor 5 untuk gelas yang paling penuh. Sebagian besar siswa menyusun gelas dari atas ke bawah, tetapi ada satu siswa yang bernama Amirah yang memilih untuk menyusun gelas dari kiri ke kanan tanpa memperhatikan nomor yang telah diberikan pada worksheet.

Dari pre-test ini dapat dilihat kemampuan awal siswa mana yang masih belum mengenal ukuran maupun siswa yang telah mengenal ukuran sehingga peneliti memiliki gambaran untuk aktivitas pembelajaran selanjutnya.

Tahapan selanjutnya adalah memulai aktivitas pembelajaran. Pada saat pelaksanaan aktivitas pembelajaran siswa dibimbing guru secara langsung untuk mencoba menuangkan air dan melihat perbandingan isi air. Guru memberikan beberapa pertanyaan yang bisa membimbing siswa mencapai tujuan pembelajaran.

Disini guru berperan sebagai fasilitator untuk membimbing anak agar dapat mengenal ukuran.

Berdasarkan teori Piaget (Ormrod, 2009), anak usia 4 tahun masih berada pada tahap praoperasional. Tahap praoperasional sendiri terdiri dari tahap praoperasional dan intuitif. Pada tahap ini, anak mulai memperoleh pengetahuan dan menarik kesimpulan. Jawaban siswa pada saat aktivitas pembelajaran sesuai dengan teori Piaget, dimana siswa menjawab pertanyaan guru berdasarkan pengalaman dan pengetahuan siswa.

Pada aktivitas pembelajaran, siswa sudah mulai lebih banyak bereksplorasi. Hal ini bisa dilihat dari salah satu siswa, yaitu Fathir yang sudah bisa mengaitkan aktivitas pembelajaran dengan konsep waktu dimana botol dengan kapasitas yang lebih besar memerlukan waktu yang lebih banyak untuk terisi penuh jika dibandingkan dengan botol dengan kapasitas yang lebih kecil. Ini berarti Fathir memiliki pengalaman yang lebih banyak tentang waktu dibandingkan dengan teman sebayanya sehingga dia dapat menarik kesimpulan berdasarkan pengalamannya.

Beberapa siswa juga sudah dapat mengenal ukuran dan memahami bahwa botol yang besar memiliki lebar dan tinggi yang lebih jika dibandingkan dengan botol yang kecil, sehingga air di dalam botol besar terlihat lebih sedikit jika dibanding botol kecil walaupun volume air dari kedua botol itu sama. Pembelajarn ini dapat menambah pengalaman siswa sehingga siswa sudah memiliki konsep tentang mengenal ukuran.

Pada aktivitas pembelajaran ini, secara keseluruhan siswa terlihat antusias dengan kegiatan pembelajaran. Hal ini dapat dilihat pada saat guru mulai mengeluarkan alat peraga dan menjelaskan permainan yang akan digunakan pada saat pembelajaran. Hal ini bagus untuk meningkatkan minat siswa dalam memulai pembelajaran.

Tetapi, pada saat guru meminta siswa untuk maju mengerjakan praktik secara bergrup yang terdiri dari dua orang siswa, beberapa siswa terlihat pasif dan perlu lebih banyak perhatian dan rangsangan agar siswa dapat menjawab pertanyaan guru dan lebih berani dalam mengemukakan pendapatnya.

Hal menarik yang terjadi dalam 
penelitian ini adalah ada satu siswa yang bernama Fathir, pada saat aktivitas pembelajaran Fathir berada dalam satu grup dengan Naya. Pada saat pre-test pertama dan kedua, Fathir tidak bisa menjawab worksheet yang diberikan dengan baik. Tetapi, pada saat aktivitas pembelajaran, Fathir bisa mengikuti kegiatan dengan baik dan memberikan pendapat yang ada di luar prediksi peneliti dan guru model. Fathir bisa menjelaskan perbedaaan isi air berdasarkan pengetahuan maupun pengalaman yang dia dapat, seperti menghubungkan situasi bahwa botol yang besar perlu waktu yang lebih lama jika ingin diisi penuh dibanding botol kecil yang memerlukan waktu lebih sedikit.

Pada saat aktivitas pembelajaran juga, Fathir terlihat lebih aktif dalam memberikan pendapat dibandingkan dengan temannya di dalam grupnya. Berdasarkan penuturan dari guru model juga diketahui bahwa Fathir memang lebih menyukai aktivitas pembelajaran aktif dimana dia bisa terlibat langsung dengan bergerak dan melakukan percobaan dibandingkan jika dia harus menulis dan membaca.

Grup yang menunjukkan hasil sesuai dengan prediksi peneliti dan guru model adalah grup Dimaz dan Felicia. Selama aktivitas berlangsung Felicia terlihat pasif dan tidak banyak berkomentar. Tetapi, Dimaz dapat memberikan komentar menjawab pertanyaan guru dengan baik. Dimaz telah bisa membandingkan isi air yang lebih banyak dan lebih sedikit. Dimaz juga telah mengenal ukuran dengan baik. Hal ini terlihat dari penyataannya yang mengatakan bahwa botol yang besar memiliki lebar yang lebih dari botol yang kecil. Botol yang besar juga lebih tinggi dari botol kecil sehingga jika air diisi ke dalam botol kecil air terlihat lebih tinggi dari botol yang besar.

Grup yang lainnya adalah grup yang terdiri dari Rangga dan Amirah, Erica dan Nabila, dan Shavrille dan Afiqah. Ketiga grup ini dapat melakukan aktivitas sesuai dengan petunjuk dari guru model. Tetapi selama aktivitas ketiga grup ini tidak terlalu banyak memberikan pendapat. Ada beberapa faktor yang mempengaruhinya, diantaranya seperti pada grup Erica dan Nabila. Erica mencoba untuk mengikuti petunjuk dan menjawab pertanyaan dari guru, tetapi Nabila tidak fokus dengan petunjuk guru karena perhatiannya terganggu oleh adanya peneliti yang merekam aktivitas pembelajaran. Di beberapa momen terlihat Nabila lebih memilih untuk melihat dan tersenyum ke kamera.

Untuk kedua grup lainnya, yaitu Rangga dan Amirah dan Sahvrille dan Afiqah dapat mengikuti instruksi guru dengan baik. Tetapi siswa masih perlu dorongan lebih lagi untuk lebih aktif dalam menyampaikan pendapatnya ketika berdiskusi dalam aktivitas pembelajaran. Karena selain dari aspek kognitif yang berkembang, aktivitas pembelajaran ini diharapkan dapat mengembangkan aspekaspek yang lain seperti aspek bahasa yang dilihat dari berkomunikasi dalam menyampaikan pendapat dan ide-idenya dan juga aspek sosio-emosional yang dilihat dari bagaimana siswa berinteraksi dengan guru dan teman-temannya.

Secara keseluruhan, dari aktivitas pembelajaran ini diharapkan siswa tidak hanya mengembangkan aspek kognitifnya saja, tetapi dapat juga mengembangkan aspek sosio-emosional dengan lebih banyak interaksi terhadap guru dan teman sebayanya, dan juga mengembangkan aspek linguistik siswa, dimana siswa dapat memahami pertanyaan-pertanyaan dari guru maupun temannya dan juga belajar untuk menjawab pertanyaan dan menyampaikan pendapat secara jelas.

Setelah dilaksanakan aktivitas pembelajaran dalam mengenal ukuran siswa diberikan tes akhir (post-test). Tes akhir ini bertujuan untuk melihat dan membandingkan pemahaman siswa dalam mengenal ukuran. Tes akhir ini berupa tes langsung tidak tertulis. Guru memberikan lima buah gelas yang berisi air yang 
berbeda isinya. Kemudian siswa diminta untuk menyusun gelas berdasarkan isi air yang ada di dalam gelas. Siswa diminta untuk menyusun secara berurutan dari gelas yang berisi paling sedikit air ke gelas yang berisi paling banyak air. Siswa dapat melihat dan menyusun air dari tinggi air di dalam gelas karena air sudah ditempatkan di gelas yang memiliki kapasitas yang sama.

Pada saat tes akhir (post-test), sebagian besar siswa sudah menyusun gelas yang berisi air berdasarkan isinya. Ada delapan siswa yang dapat menyusun air dengan benar dan masih ada dua siswa yang belum bisa menyusun air dengan benar. Dengan demikian, dapat disimpulkan bahwa pengetahuan dan kemampuan dalam mengenal ukuran telah mengalami peningkatan.

\section{PENUTUP}

Berdasarkan hasil penelitian dan pembahasan yang telah diuraikan maka dapat disimpulkan bahwa permainan menuangkan air sebagai konteks dalam pembelajaran anak usia dini untuk memahami ukuran memiliki peranan penting dan dapat digunakan sebagai starting point pada pembelajaran, dapat mendukung kemampuan siswa dan menyelesaikan permasalahan sehari-hari siswa yang terkait dengan masalah ukuran banyak atau sedikit. Selanjutnya diharapkan bagi peneliti lain agar dapat mengembangkan lagi aktivitas pembelajaran aspek perkembangan kognitif pada anak usia dini sehingga menjadi lebih bermakna lagi.

\section{DAFTAR PUSTAKA}

Akker,et al. (2006). Education Design Research. London: Routledge Taylor and Francis Group.

Bakker, A. (2004). Design Research in Statistics Education on Symbolizing and Computer Tools. Amersfoort: Wilco Press.

Gravemeijer, K. P. E (2004). Local Instructional Theories as Means of Support for Teacher in Reform Mathematics Education. Mathematical Thinking and Learning, 6(2), 105-128, Lawrence Erlbaum Association, Inc.

Gravemeijer, K. P. E., \& Van Eerde, D. (2009). Design Research as a Means for Building a Knowledge Base for Teaching in Mathematics Education. The Elementary School Journal,109(5).

Ormrod, Jeanne Ellis. (2009). Psikologi Pendidikan Membantu Siswa Tumbuh dan Berkembang. Jakarta: Erlangga.

Papadakis, S., Kalogiannakis, M., \& Zaranis, N. (2016). Improving Mathematics Teaching in Kindergarten with Realistic Mathematical Education. Early Childhood Educ J. Springer.

Putri, R.I.I. (2012). Pendisainan Hypotetical Learning Trajectory (HLT) Cerita Malin Kundang Pada Pembelajaran Matematika. Dalam Prosiding Seminar Nasional Matematika dan Pendidikan Matematika. Yogyakarta, 10 November 2012. Universitas Negeri Yogyakarta.

(2015). Professional Development Of PMRI Teachers For Introducing Social Norms. IndoMSJME, Vol 6 No 1 Hal. 11-19.

Soedjadi, R. (2007). Inti Dasar-Dasar Pendidikan Matematika Realistik Indonesia. Jurnal Pendidikan Matematika, Vol 1, No. 2, Juli 2007, hlm 1 - 10. Palembang : Universitas 
Sriwijaya

Sudono, Anggani. (2004). Sumber Belajar dan Alat Permainan (Untuk Pendidikan Anak Usia Dini). Jakarta: Grasindo.

Suparno, Paul. (2001). Teori Perkembangan Kognitif Jean Piaget. Yogyakarta: Kanisius.

Undang-Undang Republik Indonesia Nomor 20 Tahun 2003 tentang Sistem Pendidikan Nasional

Wijaya, Ariyadi. (2008a). Design research in mathematics education Indonesian traditional games as preliminaries in learning measurement of length. Dalam Prosiding Konferensi Nasional Matematika XIV, Palembang, tanggal 24 s.d. 27 Juli 2008, hal. 731-738. Universitas Sriwijaya.

(2008b). Design research in mathematics education: Indonesian traditional games as means to support second graders' learning of linear measurement.
Thesis Utrecht University. The Netherland: Utrecht Univesity.

Matematika Realistik: Suatu Alternatif Pendekatan Pembelajaran Matematika. Yogyakarta: Graha Ilmu.

Zaranis, N., Kalogiannakis, M., \& Papadakis, S. (2013). Using Mobile Devices for Teaching Realistic Mathematics in Kindergarten Education. Creative Education, 4, 110.

Zulkardi. (2002). Developing A Learning Environment on Realistik Mathematics Education for Indonesian Student Teachers. Doctoral thesis of Twente University. Enschede: Twente University.

Zulkardi \& Putri, R Ilma. (2006). Mendesain Sendiri Soal Kontekstual Matematika. Paper terseleksi dan dipublikasikan pada prosiding KNM 13 Semarang, 2006 